\title{
ANALISA FAKTOR-FAKTOR DAN PENYELESAIAN SAAT TERJADI SALAH TAKSIR YANG DILAKUKAN OLEH PENAKSIR PADA PRODUK RAHN (STUDI KASUS PT. BPRS BHAKTI SUMEKAR KABUPATEN SUMENEP)
}

\author{
Nobi Iskandar \& Amran Suadi \\ Email: noiskan@yahoo.com
}

\begin{abstract}
Abstrak
Penelitian tesis ini merupakan hasil dari analisa faktor-faktor yang mengakibatkan kesalahan tafsir yang dilakukan oleh penaksir, serta bagaimana proses penyelesaian yang dilakukan oleh pihak PT. BPRS Bhakti Sumekar pada masalah selisih harga kurang saat lelang barang agunan emas pada produk rahn. Bagaimana perhitungan yang dilakukan oleh pihak Bank dan Tim Audit lelang dalam menentukan besrnya selisih yang harus ditanggung oleh penaksir. Besarnya biaya pelunasan yang harus dibayar oleh peminjam dari tanggal jatuh tempo sampai acara peleangan.

Metode yang dipergunakan adalah metode kualitatif deskriptif. Metode kualitatif merupakan suatu paradigma penelitian untuk mendeskripsikan peristiwa, fenomena, perilaku orang atau suatu keadaan pada tempat tertentu secara rinci dan mendalam dalam bentuk narasi. Jenis penelitian ini adalah penelitian lapangan (field reseacrh). Pendekatan yang digunakan adalah Studi kasus merupakan salah satu jenis pendekatan kualitatif yang menelaah sebuah "kasus" tertentu dalam konteks atau setting kehidupan nyata kontemporer. Studi kasus merupakan jenis penelitian yang mendalam tentang individu, satu kelompok, satu organisasi, satu program kegiatan, dan sebagainya dalam waktu tertentu.

Hasil penelitian menemukan bahwa kesalahan taksir yang dilakukan oleh penaksir mengakibatkan terjadinya salah taksir pada barang agunan emas yang dilelang oleh pihak Bank. Hal ini menyebabkan ada selsih kurang pada pelunasan pembayaran penerima pinjaman. Namun, melihat dari sebab terjadinya selisih harga yang diakibatkan oleh kesalahan penaksir, maka sesuai dengan bentuk kerja sama yang telah disepakati, beban selisih kurang tersebut ditanggung oleh pihak penaksir. Peminjam hanya diwajibkan memenuhi pelunasan biaya pemeliharaan dari tanggal jatuh tempo sampai tanggal pelelangan. Perlu ada yang melakukan penelitian serupa yang lebih baik sehingga apa yang sudah diteliti dan disusun ini memperoleh perbaikan dan semakin luas pemahaman mengenai tugas dan tanggung jawab penaksir.
\end{abstract}

\section{Kata Kunci : Rahn, Penakisr, Faktor-Faktor Kesalahan Taksir}

\section{PENDAHULUAN}

Dalam persoalan ekonomi khususnya yang berprinsip syariah, juga bermacam macam diantara jenis kerja sama dan tolong menolong yang telah membudaya di kalangan masyarakat yakni pinjam meminjam dan utang-piutang. Oleh karena itu, terciptalah sebuah lembaga pemerintah yang dapat membantu masyarakat mendapatkan sejumlah dana segar tanpa harus kehilangan barang berharga yang mereka miliki ataupun tepaksa meminjam dengan bunga yang sangat tinggi, lembaga tersebut yaitu lembaga baik bank maupun non bank yang salah satu produknya adalah gadai.

Gadai merupakan salah satu kategori dari perjanjian utang piutang, yang mana untuk suatu kepercayaan dari orang yang berpiutang, maka orang yang berutang menggadaikan barangnya sebagai jaminan terhadap utangnya itu. Barang jaminan tetap milik orang yang menggadaikan (orang yang berutang) tetapi dikuasai oleh penerima gadai (yang berpiutang). 
Dalam memberikan pinjaman, pegadaian harus menerima barang yang bernilai ekonomis yang dijadikan sebagai jaminan dari debitur, sebagai syarat apabila debitur tidak dapat melunasi pinjamannya, setelah melalui peringatan terlebih dahulu, namun tidak diindahkan dan tidak meakukan perpanjangan, maka lembaga pegadaian mempunyai hak untuk mengambil pelunasan piutangnya dengan cara melelang barang jaminan gadai yang dibawah kekuasaannya.

Sebelum Indonesia merdeka, lembaga pegadaian sudah didirikan meskipun pada awalnya merupakan lembaga swasta. Hal ini berkelanjutan hingga pada awal-awal kemerdekaan. Sehingga, pada tahun 1961, berdasarkan Peraturan Pemerintah Nomor 178 Tahun 1961 lembaga itu berubah menjadi perusahaan negara. Selanutnya, berdasarkan Keputusan Presiden Nomor 108 tahun 1965 Perusahaan Negara Pegadaian diintegrasikan ke dalam urusan Bank Sentral. Berdasarkan Peraturan Pemerintah Nomor 7 Tahun 1969 Perusahaan Negara Pegadaian diubah statusnya menjadi Perusahaan Jawatan Pegadaian.

System perbankan di Indonesia diatur dalam UU No. 7 Tahun 1992. Perbankan di Indonesia terdiri dari 2 jenis, yaitu bank umum dan bank perkreditan rakyat. Kedua jenis bank tersebut melaksanakan kegiatan konvesional dan syariah secara berdampingan (dualbanking system $=$ system perbankan ganda) .

Bank syariah dalah bank yang melaksanakan kegiatan usaha berdasarkan prinsip Syariah, yaitu aturan perjanjian berdasarkan Hukum Ekonomi Stari'ah. Dalam menjalankan usahanya, bank syariah menggunakan pola bagi hasil yang merupakan landasan utama dalam segala operasinya. Produk-produk bank syariah mempunyai kemiripan tetapi tidak sama dengan bank konvesional, yaitu harus menghindari unsur-unsur yang dilarang.

Banyak produk di bank syaria'ah yang akhir akhir ini banyak diminati oleh masyarakat menengah kebawah adalah produk gadai, yang merupakan produk unggulan dalam satu tahun mencapai $85 \%$ . Produk gadai emas perhiasan merupakan produk bank syari/ah yang menggunakan akad Rahn, Ijarah dan Qarad.

Produk gadai emas di bank syariah beroperasi didasarkan pada fatwa DSN MUI No 26/DSN-MUI/III/2002 gadai emas syariah yang harus memenuhi ketentuan umum sebagai berikut:

\begin{tabular}{llr}
$\stackrel{\text { a. }}{\text { Rahn }}$ & \multicolumn{1}{c}{ Rahas } \\
dibolehkan & berdasarkan & prinsip \\
rahn & &
\end{tabular}

b. Ongkos dan biaya penyimpanan barang (marhun) ditanggung oleh penggadai ( $r a h n)$

c. Ongkos

penyimpanan besarnya didasarkan pada pengeluaran yang nyata-nyata diperlukan

d. Biaya penyimpanan barang (marhun) dilakukan berdasarkan akad ijarah

Namun pada kenyataannya permasalahan - permasalahan mulai muncul saat nasabah tidak dapat menebus emasnya untuk membayar hutang pada saat jatuh tempo. Sesuai dengan peraturan di Bank, apabila pada saat jatuh tempo nasabah tidak dapat membayar hutang dengan menebus emas mereka, maka akan dilakukan pelelangan atau penjualan objek jaminan milik nasabah.

Disamping permasalahan di atas, permasalahan yang akan dicermati dan diteliti yaitu apakah ada perbedaan dasar penaksiran harga emas yang digunakan, pada saat terjadi akad dasar harga emas yang digunakan di pegadaian dan bank dengan harga emas di pasar.

Untuk menghindari hal tersebut sebaiknya pada saat melakukan akad maka nasabah meminta dijelaskan dan pihak bank harus menjelaskan rincian hitungan dan dasar perhitungan penaksiran emas serta dijelaskan pula dasar harga emas yang digunakan, jika memang ada perbedaan atau selisih dengan harga emas pasar harus dijelaskan dari awal sehingga 
akad yang dilakukan menjadi jelas dan tidak ada yang mengganjal.

Seperti permasalahan yang pernah terjadi pada PT. BPRS Bhakti Sumekar pada tahun 2017. gambaran permaslahannya sebai berikut: si Fulan memiliki perhiasan berupa liontin yang ingin dijadikan sebagai barang agunan untuk pengajuan dana Rahn pada PT. BPRS Bhakti Sumekar. setelah si Fulan mendatangi kantor PT. BPRS Bhakti Sumekar pada tanggal 23 Nopember 2017, pihak Bank melakukan pengecekan kepada perhiasan milik si Fulan. sehingga menghasilkan taksiran berat liontin si Fulan sebesar 4,85 gr dengan kadar Emas sebesar $85 \%$. pada saat itu harga emas di Bank sebesar Rp. 478.000,-. dari taksiran tersebut harga taksiran liontin si Fulan Sebesar Rp. 1.969.698,- dan si Fulan mendapatkan dana plafon sebesar Rp. 1. 772.000 ,- berdasarkan perhitungan 0,90\% dari harga taksiran. dana bersih yang dapat diterima oleh si Fulan adalah sebesar Rp. 1.755.001,- setelah dikurangi atas biaya taksiran. namun setelah beberapa bulan pembayarang, ternyata si Fulan melakukan wanprestasi terhadap PT. BPRS Bhakti Sumekar. si Fulan tidak melakukan pembayaran atas pinjamannya sampai tanggal jatuh temponya. pihak Bank telak melakukan peringatan kepada si Fulan sesuai prosedur yang ada. namun peringatan tersebut tidak diindahkan oleh si Fulan. pada akhirnya pihak Bank memutuskan untuk melakukan pelelangan jaminan Rahn milik si fulan pada tangggal 23 Februari 2018. saat pelelangan harga liontin si Fulan mendapatkan penawaran harga sebesar Rp. 1.000.000,- dari harga jual yang ditetapkan oleh tim lelang sebesar Rp. 1. 150. 000,-

Penyajian data-data yang didapat dari lapangan oleh penulis disajikan dalam bentuk deskriuptif., penyajian gambar baik itu dari hasil wawancara, dokumentasi maupun observasi dan bukan berupa angka. Sedangkan bentuk penyajian datanya berupa kualitatif yaitu dengan pertimbangan menyesuaikan metode kualitatif lebih mudah dilakukan bila berhadapan dengan kenyataan ganda. Sehingga jenis penelitian ini termasuk dalam kategori jenis penelitian deskriptif kualitatif.

Pendekatan yang digunakan oleh peniliti dalam penelitian ini adalah metode studi kasus. Penelitian studi kasus yang dikemukakan oleh Yin adalah sebuah metode penelitian yang secara khusus menyelidiki fenomena kontemporer yang terdapat dalam konteks kehidupan nyata, yang dilaksanakan ketika batasan-batasan antara fenomena dan konteksnya belum jelas dengan meggunakan berbagai sumber data. jadi penelitian studi kasus merupakan penelitian yang mengungkap fonomena atau peristiwa yang terjadi dilapangan yang berhubungan langsung dengan kehidupan individu maupun kelompok. kemudian dalam kasus atau perustiwa akan dikaji dari berbagai teori atau keilmuannya.

Jenis data yang digunakan oleh peneliti adalah data primer. data primer merupakan jenis data yang dikumpulkan dan diolah peneliti secara langsung dari lapangan, melalui observasi dan interview yang berupa informasi melalui wawancara kepada pihak pelaku dalam hal ini adalah penaksir, Nasabah dan Karyawan Bank tentang tanggung jawab dan penyelesaian penaksir saat terjadi salah taksir pada produk Rahn PT. BPRS Bhakti Sumekar Kabupaten Sumenep.

Subyek penelitian berupa informan yang akan di minta keterangannya tentang obyek yang akan diteliti. Para informan tersebut diantaranya adalah Penaksir yang bertindak sebagai mitra kerja perusahaan PT. BPRS Bhakti Sumekar dan karyawan/Staf audit yang membawahi produk Rahn pada PT. BPRS Bhakti Sumekar.

Sedangkan obyek penelitian adalah Tanggung jawab penaksir saat terjadi kesalahan taksir pada produk Rahn PT. BPRS Bhakti Sumekar beserta 
penyelesaiannya ditinjau dari Hukum Ekonomi Syariah.

Sumber data yang dibutuhkan agar tercapainya tujuan dalam penelitian adalah :

1) Sumber Data Primer

Yaitu pengolahan sumber

data yang dikumpulkan oleh peneliti secara langsung dari lapangan, melalui observasi dan interview berupa informasi melalui wawancara kepada pihak pelaku, berbagai tokoh masayarakat dan tokoh agama tentang Analisis Tanggung Jawab Kesalahan Penaksir dan Penyelesaian Selisih Kurang Saat Lelang Pada Produk Rahn Studi Kasus PT. BPRS Bhakti Sumekar Kabupaten Sumenep.

2) Sumber Data Sekunder

Yaitu sumber data yang dijadikan acuan landasan teori dalam pembahasan seperti buku-buku, karya ilmiah dan sumber-sumber lainnya yang relevan dengan pembahasan objek permasalahan dari penelitian.

metode yang digunakan oleh peneliti untuk mendapatkan dan mengumpulkan data dalam penelitian diantaranya :

1) Interview (Wawancara)

Adalah teknik pengumpulan data yang digunakan peneliti untuk mendapatkan keterangan-keterangan lisan melalui bercakap-cakap dan bertatap muka dengan orang yang dapat memberikan keterangan.kepada peneliti. $^{1}$ Jenis wawancara yang digunakan adalah wawancara mendalam, dengan tujuannya untuk memperoleh informasi dari semua responden, tetapi susunan dan urutan kalimatnya disesuaikan dengan ciri-ciri responden. ${ }^{2}$ hal pertama yang dilakukakn oleh peneliti adalah dengan melakukan wawancara dengan narasumber secara langsung. Data yang ditanyakan oleh peneliti adalah hal-hal ada sangkut pautnya

1 Dedy Mulyana, Metodologi Penelitian Kualitatif; Paradigma baru Ilmu Komunikasi dan Ilmu sosial lainnya, (Bandung : Remaja Rosdakarya, 2004)

${ }^{2}$ Ibid., dengan Analisis Tanggung Jawab Kesalahan Penaksir dan Penyelesaian Selisih Kurang Saat Lelang Pada Produk Rahn Studi Kasus PT. BPRS Bhakti Sumekar Kabupaten Sumenep.

2) Observasi

Menurut Suharsimi Arikunto, Observasi adalah suatu metode pengamatan dan pencatatan secara sistematis mengenai fenomena-fenomena yang diselidiki atau diteliti baik itu secara langsung maupun tidak langsung. ${ }^{3}$ Observasi yang dilakukan oleh peneliti adalah observasi non partisipan, dimana tidak ada sangkut pautnya dengan peneliti dalam kehidupan subjek penelitian. Peneliti hanya akan mengadakan observasi berdasarkan fenomena yang terjadi di lapangan dengan cara mengungkapkan secara cermat dan tepat, dari hasil observasi tersebut kemudian dicatat dan diolah menjadi sebuah laporan penelitian. Data yang akan dikumpulkan dalam observasi ini seperti bagaimana analisa tanggung jawab kesalahan penaksir dalam mengatasi masalah selisih kurang saat terjadi lelang pada produk Rahn PT. BPRS Bhakti Sumekar Kabupaten Sumenep.

3) Dokumentasi

Untuk memperoleh data yang tidak dapat peneliti gali dengan metode penulisa tentang fenomena yang terjadi, maka penelliti melakukan metode dokumentasi. Dalam hal ini bisa berupa gambar, arsip, maupun dokumen penting yang ada pada PT. BPRS Bhakti Sumekar Kabupaten Sumenep yang berhubungan dengan permasalahan dalam penelitian.

$$
\text { Teknik Pemeriksaan }
$$

Keabsahan Data yang digunakan oleh peneliti adalah Trianggulasi. adapun yang dimaksud trianggulasi adalah teknik pemeriksaan keabsahan data yang memanfaatkan sesuatu yang lain di luar data untuk keperluan pengecekan atau

\footnotetext{
${ }^{3}$ Suharsimi Arikunto, Prosedur

Penelitian; Suatu Pendekatan Praktek, (Jakarta: Rineka Cipta,1991), Hlm. 189
} 
sebagai alat pembanding terhadap data itu sendiri. Teknik trianggulasi yang digunakan adalah trianggulasi sumber. Yaitu membandingkan dan mengecek balik derajat kepercayaan suatu informasi yang diperoleh dengan alat yang berbeda dalam penelitian kualitatif. Hal dilakukan dengan cara :

1) Membandingkan data hasil wawancara dengan hasil pengamatan.

2) Membandingkan hasil wawancara dengan dokumen lain.

Jadi trianggulasi

merupakan cara terbaik untuk menghilangkan perbedaan-perbedaan konstruksi kenyataan yang ada dalam konteks suatu studi sewaktu mengumpulkan data tentang berbagai kajian dan hubungan dari berbagai pandangan. Untuk itu maka peneliti dapat melakukannya dengan cara :

1) Mengajukan berbagai macam variasi pertanyaan.

2) Mengeceknya dengan berbagai sumber data.

Data yang didapat dikerjakan dan dimanfaatkan sedemikian rupa agar dapat menyimpulkan kebenarankebenaran yang dipakai untuk menjawab persoalan-persoalan yang diajukan dalam penelitian. Peneliti menggunakan analisis data model alur Miles dan Huberman, dimana dalam menjelaskan analisis data mempunyai tiga alur yaitu :

1) Reduksi data, yaitu proses pemilihan data, menggolongkan, mengarahkan, membuang yang tidak perlu dan mengorganisasikan data dengan cara sedemikian rupa hingga kesimpulan dan verifikasi.

2) Penyajian data. Dalam alur ini seluruh data-data di lapangan yang berupa dokumen, hasil wawancara dan hasil observasi akan dianalisis sehingga dapat memunculkan deskripsi tentang Analisis Tanggung Jawab Kesalahan Penaksir dan Penyelesaian Selisih Kurang Saat Lelang Pada Produk Rahn Studi Kasus PT. BPRS Bhakti Sumekar Kabupaten Sumenep.
3) Penarikan kesimpulan adalah hasil akhir dari proses analisis data, dimana peneliti akan mendeskripsikan, menganalisa dan menginterpretasikan data yang peneliti dapatkan melalui penelitian tersebut diatas.

Dalam Analisis data, peneliti menggunakan metode deskriptif kualitatif dimana dalam melakukan penelitian, peneliti akan mencoba mendeskripsikan fakta dari semua hasil penelitian di lapangan, menganalisa dan menginterpretasikannya sehingga penelitian ini dapat diketahui kebenaran konsep dari Analisis Tanggung Jawab Kesalahan Penaksir dan Penyelesaian Selisih Kurang Saat Lelang Pada Produk Rahn Studi Kasus PT. BPRS Bhakti Sumekar Kabupaten Sumenep.

\section{PEMBAHASAN}

\section{BPRS Bhakti Sumekar}

1. Konsep Gadai Syariah PT.

Simulasi perhitungan gadai emas berdasarkan akan yang sudah dilakukan antara nasabah dengan pihak Bank Dokumentasi Kantor PT. BPRS Bhakti Sumekar Kabupaten Sumenep, 2018. Misalnya seorang nasabah pada tanggal 3 Nopember 2017, dengan Surat Bukti Gadai Emas (SBGE) nomor 048R5272LD1632, dengan transaksi menggadaikan emasnya berupa perhiasan satu buah cincin, dengan kadar 23 karat dan berat 6,11 gram. Jika nasabah melunasi pinjamannya pada tanggal 3 Maret 2018, berapakah biaya pemeliharaan yang harus dibayarkan? HDE atau Harga Dasar Emas saat itu adalah Rp 509.500,- Nah, jika kita cermati ternyata waktu/periode gadai yang berlangsung adalah: 3 Nopember 2017 s.d 3 Maret $2018=(4$ bulan $)$, karena biaya pemeliharaan dihitung per hari 4 bulan.

Taksiran nilai perhiasan nasabah

$$
=(\mathrm{karat} / 24) \mathrm{x} \text { berat emas } \mathrm{x} \text { HDE }
$$

Pembiayaan (jumlah pinjaman

maksimal) yang diperoleh nasabah $=$ Taksiran $\mathrm{x}$ FTV 
Biaya Pemeliharaan yang

dibebankan ke nasabah

$=($ Taksiran $\mathrm{x}$ Rate $) \mathrm{x}$ waktu gadai

Simulasi perhitungan gadai emas

yang diterapkan PT. BPRS Bhakti Sumekar Kabupaten Sumenep adalah menggunakan akad Qardh dalam rangka Rahn. Yang dimaksud akad "Qardh dalam rangka Rahn" adalah akad pemberian pinjaman dari bank untuk nasabah yang disertai dengan penyerahan tugas agar bank menjaga barang jaminan yang diserahkan. Biaya pemeliharaan tersebut menggunakan akad ijarah. Selain ketentuan - ketentuan tersebut, ada beberapa hal yang perlu anda cermati untuk mengetahui jumlah pinjaman dana yang bisa anda bawa pulang dengan sistem gadai syariah ini, misalnya biaya administrasi yang biasanya dipungut di depan, dan biaya pemeliharaan yang umumnya dipungut di akhir atau diawal periode.

Ada beberapa hal yang perlu dicermati oleh nasabah pada saat sebelum akad, selama dalam akad maupun setelah akad tersebut selesai, yaitu :

1. Isi dari akad;

Nasabah tidak membaca akad; Ada beberapa faktor yang menyebabkan para nasabah tidak membaca akad Qard yang dibuat dengan pihak bank, yaitu karena :

a. Tulisan didalam akad tersebut sangat kecil sehingga susah untuk membacanya, dan biasanya nasabah tidak membacanya.

b. Nasabah sudah percaya kepada pihak perbankan karena pemahaman mereka dengan menggunakan akad syariah akan lebih melindungi dan tidak merugikan mereka.

$$
\text { c. Nasabah tidak }
$$

memperhatikan essensi dari akad Qard tersebut karena tidak sempat karena sudah membutuhkan uang pinjaman dan sudah percaya saja karena sudah berlogo gadai emas syariah.

2. Pihak petugas bank tidak menjelaskan.
Saat dilakukan penandatanganan akad tersebut petugas bank bagian gadai emas syariah tidak menjelaskan tentang klausal-klausal dalam akad Qard tersebut, dan hanya dijelaskan tentang kadar emas, berat emas, biaya adminitrasi, biaya pemeliharaan dan seberapa besar pembiayaan yang akan diterima oleh nasabah. Bahkan saat contoh akad yang digunakan dalam penulisan ini dimana ada konsekuensi jika nasabah meminta pembiayaan diluar ketentuan syariah, sebagai contoh seharusnya pembiayaan yang sesuai dengan syariah sebesar Rp. 2.535.834,57, tetapi manakala nasabah hanya mengambil pembiayaan sebesar Rp. 2.000.000,--

3. Nasabah tidak bertanya tentang rincian perhitungan;

Bagaimana menghitung nilai taksiran. $=(\mathrm{karat} / 24) \mathrm{x}$ berat emas $\mathrm{x}$ HDE

4. Ketentuan tentang biaya administrasi

Untuk biaya administrasi ini sudah ditentukan oleh kantor pusat Bank Syariah Mandiri, dan besarnya setiap bank berbeda sesuai dengan kebijakan masing-masing.

Besaran biaya administrasi yang dibebankan Bank pada nasabah dibuat dengan metode tiring mengikuti jumlah besarnya nilai taksiran. Artinya, semakin besar nilai taksiran yang digadaikan maka akan semakin besar biaya administrasi yang dibebankan pada nasabah.

5. Ketentuan tentang biaya sewa tempat (Ijarah).

Biaya Sewa Tempat adalah sejumlah uang yang dibayar oleh nasabah kepada bank sebagai biaya atas jasa penyimpanan dan pengamanan barang jaminan oleh bank. Komponen biaya ini adalah biaya tenaga sumber daya manusia untuk operasional pemeliharaan (keamanan) barang, biaya segel keamanan, biaya CCTV ruang penyimpanan barang dan biaya brankas tahan api yang disediakan, dan biaya atas fasilitas IT.

Biaya sewa tempat wajib dilunasi nasabah pada saat akhir masa pembiayaan, sedangkan pengakuan biaya tersebut 
digunakan term per 4 bulan. Artinya, biaya sewa tempat nasabah akan di-accrue oleh bank per 4 bulan sehingga secara keuangan sudah bisa diakui sebagai piutang pendapatan sewa. Untuk PT. BPRS Bhakti Sumekar menggunakan istilah Biaya pemeliharaan dengan rumus : Biaya Pemeliharaan yang dibebankan ke nasabah $=($ Taksiran $\mathrm{x}$ Rate $) \mathrm{x}$ waktu gadai

Adapun pengakuan pendapatan sewa dengan menggunakan term atau fathroh per 4 bulan sesuai dengan Hukum Islam dalam hal pengambilan ujroh. Dalam Konsep Akad Ijarah dinyatakan bahwa ujroh akan menjadi wajib dibayar oleh musta'jir dan dapat dimiliki oleh mu'jir, salah satunya, jika musta'jir membayar atas penggunaan objek sewa secara bertahap berdasarkan waktu penggunaan. Artinya, kepemilikan ujroholeh mu'jir adalah mengikuti kepemilikan manfaat objek sewa yang diterima musta'jir. Metode pembayaran ujroh dengan cara mengikuti hari atau mengikuti peringkat merupakan metode didasari pada dalil istihsân.

6. Bagaimana menghitung besarnya pembiayaan syariah

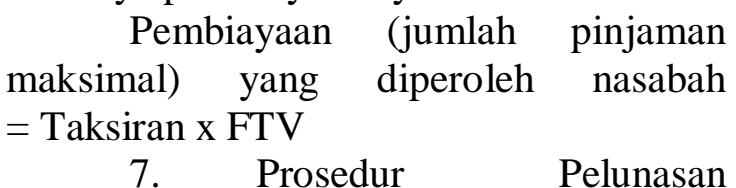
Pembiayaan Gadai Emas Syariah di PT. BPRS Bhakti Sumekar Kabupaten Sumenep.

Pada dasarnya nasabah dapat melunasi kewajibannya setiap waktu tanpa menunggu jatuh tempo. Prosedur pelunasan pada PT. BPRS Bhakti Sumekar sebagai berikut ${ }^{4}$ :

1. Nasabah datang langsung ke PT. BPRS Bhakti Sumekar dan masuk ke ruang pelaksana gadai. Nasabah dapat melakukan pembayaran dengan membayar pinjaman pada saat jatuh tempo atau nasabah dapat mengangsur setiap bulannya.

\footnotetext{
${ }^{4}$ Berdasarkan wawancara tidak terstruktur dengan Samsul Hadi -Tim Audit PT. BPRS Nhalti Sumekar.
}

2. Pada saat pelunasan, nasabah juga harus membayar biaya pemeliharaan selama jangka waktu pinjaman yang telah ditentukan.

3. Jika nasabah tidak mampu melunasi kewajibannya, pegawai gadai akan menjual barang jaminan emas yang digadaikan. Penjualan barang jaminan emas harus mendapat persetujuan dari pihak pemberi gadai.

4. Barang jaminan dikeluarkan oleh pegawai gadai emas syariah.

5. Jika nasabah sudah mampu melunasi sesuai dengan pembiayaan yang didapat, maka barang jaminan emas akan diserah terimakan kembali kepada nasabah.

8. Proses Pelelangan Barang Gadai Emas di PT. BPRS Bhakti Sumekar Kabupaten Sumenep.

Pihak gadai emas melakukan pelelangan harta benda yang menjadi barang jaminan bila pemberi gadai tidak dapat melunasi kewajibannya sampai batas waktu yang telah ditentukan dalam akad. Pelelangan dilakukan oleh pelaksana gadai emas setelah memberitahukan kepada pemberi gadai sebelum penjualan. berikut :

Ketentuan pelelangan sebagai

1. Pihak bank melakukan pelelangan terbatas, yaitu hanya memilih beberapa orang pembeli. Jadi harga penawaran yang dilakukan oleh banyak pembeli tidak diperbolehkan karena dapat merugikan rahin.

2. Pelelangan atau penjualan dilakukan oleh pihak bank yaitu pelaksana gadai.

3. Hasil pelelangan akan digunakan untuk biaya penjualan $1 \%$ dari harga jual, biaya pinjaman, dan sisanya dikembalikan kepada rahin.

9. Perpanjangan Gadai Emas Syariah

Jika nasabah belum mampu melunasi pinjamannya pada jangka waktu yang telah ditentukan di akad, maka nasabah dapat mengajukan perpanjangan 
gadai emas syariah dengan membayar biaya pemeliharaan dan angsuran pembiayaan serta menandatangani akad baru. Di Bank Syariah Mandiri, memberikan kebijakan dua kali perpanjangan untuk gadai emas syariah. Dan kebijakan ini banyak dipakai oleh pihak bank untuk mencegah terjadinya kredit macet, dan juga dimanfaatkan para nasabah agar tidak sampai kehilangan perhiasan yang digadaikan tersebut.

2. Analisa Selisih Harga Taksiran

Mengacu pada permasalahan yang dialami PT. BPRS Bhakti Sumekar pada tahun 2017, Atas wanprestasi yang dilakukan oleh si Fulan sebagai pemilik perhiasan berupa liontin yang dijadikan sebagai barang agunan untuk pengajuan dana rahn dan terjadinya salah taksir yang dilakukan oleh penaksir saat pelelangan. Peneliti mengulas secara rinci selisih harga yang dialami oleh si Fulan dengan metode perhitungan sebagai berikut :

$$
\text { Harga taksiran }=\text { Kadar }
$$

Emas x Harga Emas x Berat Emas

$478.000,-$ x 4,85 gr

$$
=85 \% \times \mathrm{Rp} \text {. }
$$

969.698,-

$$
=\operatorname{Rp} \cdot 1 \text {. }
$$

Pembiyaan (Jumlah Pinjaman Maksimal) yang diperoleh nasabah :

$$
=\text { Taksiran } \mathrm{x}
$$

$90 \%$

$$
\begin{array}{llll}
1.969 .698,-\times 90 \% & = & \text { Rp. } \\
& = & \text { Rp. } & 1 .
\end{array}
$$$$
\text { 772.728,- }
$$

Namun, setelah liontin si Fulan dilelang karena tindakan wanprestasi si Fulan, mendapatkan taksiran sebagai berikut. Menurut hasil penawaran peserta, harga liontin si Fulan sebesar Rp. 1.000.000,- dari nilai taksiran sebesar Rp. 1.969.698,- namun harga tersebut terlalu rendah untuk disetujui, sehingga tim audit menjual liontin si Fulan dengan harga sebesar Rp. 1.150.000,-. Sedangkan kewajiban pelunasan si Fulan sebesar Rp.
2.050.498,-. Maka, selisih harga pada saat lelang sebagai berikut :

Kewajiban pelunasan - Harga jual lelang $=$ Selisih Harga

Rp.2.050.498 - Rp. 1.150.000,- = Rp. 900.498,-

Selisih yang dihasilkan dari perhitungan tersebut, nantinya akan ditanggung oleh penaksir. Karena keruguian yang dialami oleh pihak Bank atas taksiran liontin si Fulan akibat kesalahan taksir oleh penaksir. Sesuai dengan isi kontrak kerja antar pihak Bank dan Penaksir

3. Analisa Faktor-Faktor dan Penyelesaian Saat Terjadi Salah Taksir Yang Dilakukan Oleh Penaksir Pada Produk Rahn (Studi Kasus PT. BPRS Bhakti Sumekar Kab. Sumenep).

a. Faktor-Faktor Salah Taksir Penaksir adalah mitra kerja PT. BPRS Bhakti Sumekar yang bertugas untuk melakukan kegiatan penilaian atas barang yang akan dijadikan agunan pada produk rahn.

Fungsi penaksiran tidak lain untuk menentukan batas jumlah pinjaman yang diberikan kepada peminjam sesuai dengan jaminan yang diberikan agar tidak melebihi ataupun kurang dari harga pasar.

Penaksir sebagai ujung tombak perusahaan memiliki tugas dan tanggung jawab yang sangat krusial bagi kegiatan oprasional PT. BPRS Bhakti Sumekar. Maju mundurnya perusahaan tergantung kepada kualitas taksiran yang dihasilkan oleh para penaksir. Untuk itu, penaksir memegang fungsi yang sangat penting didalam kegiatan oprasional khususnya dalam memberikan pelayanan yang terbaik kepada masyarakat.

Sebagai salah satu fungsi dari kegiatan oprasional tersebut, maka fungsi penaksir mencerminkan citra dan kualitas pelayanan yang dapat diberikan oleh PT. BPRS Bhakti Sumekar. Proses kerja tersebut dapat dijelaskan sebagai berikut : 
a. Penaksir menetukan
taksiran atas barang jaminan yang diserahkan oleh nasabah.

b. Taksiran yang baik akan menghasilkan uang pinjaman yang baik pula.

c. Uang pinjaman yang baik akan menghasilkan sewa modal yang optimal. Sebaliknya taksiran yang buruk (Taksiran Tinggi/Randah) akan menghasilkan uang pinjaman yang bermasalah.

d. Taksiran tinggi akan menyebabkan terhambatnya perputaran modal kerja dan Cost Of Capital yang tinggi karena perlu penanganan yang lebih lanjut atas kasus taksiran tinggi. Taksiran rendah akan menyebabkan uang pinjaman rendah dan pendapatan sewa modal yang rendah pula, disamping itu kepercayaan masyarakat kepada PT. BPRS Bhakti Sumekar akan semakin rendah karena barang mereka ditaksir rendah oleh penaksir.

Pada kenyataannya, dalam pekerjaanya penaksir bukan berarti tidak pernah melakukan kesalahan. Baik dari intern penaksir maupun dari bantuan alatalat taksir yang memiliki kualitas kurang baik. Masih banyak kesalahan yang dilakukan oleh penaksir yang dapat menimbulkan kerugian kepada penaksir, pihak BANK, bahkan nasabah. Kesalahankesalahan itu, diakibatkan oleh :

1) Kesalahan timbangan, pada proses ini kesalahan yang terjadi dapat diakibatkan oleh alat timbang yang tak mampu beroprasi fengan baik. Atau proses penimbangan yang kurnag tepat sehingga mengakibatkan kesalahan timbangan.

2) Salah kadar, penentuan kadar emas sangatlah sulit. Membutuhkan pengalaman bertahun-tahun untuk mengetahui tinggi rendahnya kadar emas pada perhiasan. Kemampuan tersebut tak hanya bisa dilakukan dengan mengikuti pelatihan-pelatihan singkat yang mengandalkan keabsahan sertifikat yang didapat. Semakin lama pengalaman penaksir dalam dunia perhiasan akan sangat dengan mudah dapat menentukan besar kecilnya kadar emas yang ada pada perhiasan.

3) Faktor kesehatan, faktor yang satu ini datang dari intern penaksir. Dikarenakan kegiatan penaksiran ini sangat mengandalkan tingkat ketelitian seorang penaksir, maka menjaga stamina dan kesehatan tubuh menjadi syarat mutlak bagi penaksir agar dapat menjalankan tugas dengan baik dan sesuai dengan yang diharapkan.

\section{4) Air Penguji}

5) Keliru Tulis, pada kenyataannya adalah penaksir taklepas dari kehilafan saat melakukan penulisan hasil taksiran. Karena kesalahan penulisan ini terkadang penaksir harus menelan kerugian dalam kerjanya.

6) Psikis, keadaan psikologi penaksir sangat mempengaruhi tingkat kesabaran dalam menjalankan proses pengukuran emas. Sehingga tingginya kesabara penaksir mengakibatkna tingginya ketelitiaan dan kesempurnaan hasil pengukuran kadar emas.

Dari beberpa faktor yang dijelaskan diatas, pada dasarnya tidak ada faktor kesengajaan dalam setiap kesalahan yang dilakukan oleh penaksir. Semua penaksir berusaha bersikap profesional untuk memberikan kepuasan pelayanan sebagai mitra kerja.

b. Penyelesaian Saat Terjadi Kesalahan Taksir

Salah satu langkah yang dilakukan oleh PT. BPRS Bhakti Sumekar dalam mengatasi wanprestasi yang dilakukan oleh nasabah dalam produk rahn adalah menjual/melelang barang yang dijadikan agunan produk rahn.

Wanprestasi berarti melanggark tindakan yang sudah disepakati dan dapat dituntut. Wanprestasi adalah keadaan tidak dipenuhinya prestasi sebagai mana ditetapkan dalam perikatan karena kesalahan peminjam (sengaja/lalai) atau keadaan memaksa (diluar kemampuan peminjam). 
Sehingga bentuk sangksi dari peminjam yang melaklukan wanprestasi pada produk rahn adalah dilakukannya pelelangan oleh pihak bank. Suatu pelaksanaan lelang, khususnya lelang eksekusi adalah tindak lanjut dari pelaksanaan perjanjian rahn yang tidak ditepati oleh peminjam berdasarkan perjanjian rahn pada PT. BPRS Bhakti Sumekar.

Pada kegiatan lelang PT. BPRS Bhakti Sumekar diawali dengan mengundang peserta lelang yang bersangkutan dan memiliki keinginan untuk mendapatkan barang lelang seperti toko emas, pedagang emas maupun masyarakat yang telah menjadi mitra PT. BPRS Bhakti Sumekar. Dilanjutkan dengan tim lelang membuka acara lelang. Setiap peserta lelang diberikan hak untuk melihat dan mengukur emas yang akan dilelang, setiap peserta juga akan diberikan lembar penawaran harga untuk barang yang akan dilelang. Kemudian tim lelang mengumpulkan kembali lembar harga penawaran dari peserta lelang. Hal ini dilakukan untuk mencari kesepakatan harga tertinggi yang ditawarkan oleh peserta lelang. Pada akhrinya ditemukan harga tertinggi dari peserta lelang. Maka tersebut menjadi harga kesepakatan.

Dari harga tersebut akan menimbulkan perbedaan/selisih kurang harga pelunasan rahn dari pihak BANK. Tim audit melakukan pengecekan ulang terhadap nilai selisih kurang dari hasil lelang emas pada produk rahn. Sehingga, menemukan kesimpulan bahwa kesalahan taksir berat pada produk rahn dilakukan oleh penaksir. Selanjutnya, untuk menindaklanjuti masalah tersebut pihak BANK memberitahukan kepada pihak penaksir bahwa terjadi kesalahan taksir yang mengkibatkan selisih kurang pada lelang emas. Segala bentuk kerugian yang diakibatkan kesalahan taksir pada penaksir akan ditanggungkan kepada penaksir sesuai dengan kontrak kerja antara pihakn BANK dengan penaksir.

\section{KESIMPULAN}

1. Beberpa faktor yang menjadi penyebab kesalahan taksir diantaranya adalah : kesalahan timbangan, salah kadar, faktor kesehatan, air penguji, keliru tulis, dan kondisi psikologis.

2. Salah satu bentuk penanganan wanprestasi pada produk rahn PT. BPRS Bhakti Sumekar adalah dilakukan penjualan/pelelangan barang agunan dalam hal ini berupa emas.

3. Segala bentuk kerugian yang diakibatkan oleh kesalahan taksir oleh penaksir, akan sepenuhnya dibebankan kepada penaksir sesuai dengan isi kontrak kerja sama antara pihak BANK dengan penaksir.

\section{DAFTAR PUSTAKA}

Antonio, Muhammad Syafi'i, Bank Syari'ah dari Teori ke Praktik, cet. I, Jakarta: Gema Insani Press, 2001.

Arifin, Zainul, Dasar-dasar Manajemen Bank Syari'ah, edisi revisi, Jakarta: Pustaka Alvabet, 2006. Memahami Bank Syari'ah: Lingkup, Peluang, Tantangan, dan Prospek, cet. I, Jakarta: Alvabet, 1999.

Arikunto, Suharsimi, Prosedur Penelitian Suatu Pendekatan Praktek, Jakarat: PT. Rineka Cipta, 1998.

AAOIFI, Accounting and Auditing Standards for Islamic Financial Institution, Bahrain, 1998.

Bachrudin, Manajemen Pembiayaan (Kredit) Bank Syari'ah, Hand Out Mata Kuliah Manajemen Dana dan Pembiayaan Bank Syari'ah, 2007, tidak diterbitkan.

Basyir, Ahmad Azhar, Asas-asas Hukum Mu'amalah (Hukum Perdata Islam), edisi revisi, Yogyakarta, UII Press, 2000.

al-Bustani, Abdul Karim, dkk., al-Munjid fi al-Lugah wa al-A'lām, Beirut: Dār el-Machreq, 1946.

Dahlan, Abdul Aziz, (ed) dalam Ensiklopedi Hukum Islam, cet. V, 
Jakarta: Ichtiar Baru Van Hoeve, 2001.

Darmawi, Herman, Manajemen Risiko, cet. 9, Jakarta: Bumi Aksara, 2005.

Dendawijaya, Lukman, Manajemen Perbankan, Cet, II. Jakarta: Ghalia, 2003.

Hadi, Sutrisno, Metodologi Research 2, Yogyakarta: Yayasan Penerbitan Fakultas Psikologi UGM, 1984.

al-Hafiz, Ibn Rusyd, Abu al-Walid Muhammad, Bidayah al-Mujtahid wa Nihayah al-Muqtasid, Beirut: Dār al-Fikr, t.t.

Hanafi, Mamduh M, Manajemen Keuangan, cet. I, Yogyakarta: BPFE, 2004. dan Abdul Halim, Analisis Laporan Keuangan, edisi ketiga, Yogyakarta: Unit Penerbitan dan Percetakan Sekolah Tinggi Ilmu Manajemen YKPN, 2007.

Harahap, Sofyan S, Bunga Rampai; Ekonomi, Bisnis \& Manajemen Islami, cet. I, Yogyakarta: BPFE, 2004.

Haris, S.E, The National Debt and New Economic, New York: Mc Graw Hill Book Co, 1977.

Ikatan Akuntansi Indonesia, Kerangka Dasar Penyusunan dan Penyajian Laporan Keuangan Bank Syari'ah, Jakarta: Dewan Standar Akuntansi Keuangan, 2002.

al-Jaziri, Abd. Ar-Rahman, Kitab al-Fiqh 'ala al-Mazahib al-Arba'ah, Beirut: Dār al-Fikr, 1996.

Karim, Adiwarman A, IncentiveCompatible Constraints for Islamic Banking: Some Lessons From Bank Muamalat, dalam Munawar Iqbal, dkk (Ed), Islamic Banking and Finance: New Perspectives on Profit-Sharing and Risk, Edward Elgar, Montpellier Parade, Cheltenham, UK, 2000.

Kim, Saeng $\mathrm{Wi}$ and Eric Sorensen, "Evidence on the Impact of tha Agancy Cost of Debt on Corporate Debt Policy", Journal Financial and Quantitative Analysis, Vol.21, No.2.

Lewis, Mervyin dan Latifa M. Algaoud, Islamic Banking, Edward Elgar Cheltenham, UK, Northampton Massachusetts USA, 2001.

Mājah, Ibnu, Sunān Ibnu Mājah, Beirut: Dār al-Fikr, t.t.

Makmun, Tantangan Perbankan Syariah, Republika, 7 April 2008.

Moleong, Lexy J. Metodologi Penelitian Kualitatif, Bandung: PT. Remaja Rosdakarya, 2000

al-Mushlih, Abdullah dan Shalah ashShawi, Fikih Ekonomi Keuangan Islam, terj. Abu Umar Basyir,cet. I, Jakarta: Darul Haq, 2004.

Nasution, S, Metode Research(Penelitian Ilmiah), cet. VIII, Jakarta: Bmi Aksara, 2006

Perwataatmadja, Karnaen dan Muhammad Syafi'i Antonio, Apa dan Bagaimana Bank Islam, cet. III, Yogyakarta: Dana Bhakti Prima Yasa, 1999.

Prakoso, Sigit, dan Syamsul Anwar, Permasalahan Mudharabah dan Aplikasinya di Lembaga Keuangan Syari'ah, Yogyakarta: FLKS, 2001.

Presley, JR, dan Session JG, "Islamic Economic: The Emergence of a New Paradigm, The Economic Journal, Vol 104.

Qadāma, Ibn, al-Mugnī, Riyād: Maktabah al-Riyād al-Hadisah, t.t. 